\title{
ГЕНЕРАЛІЗОВАНИЙ ТРИВОЖНИЙ РОЗЛАД У МІЖНАРОДНОМУ ФОРМАТІ DSM-V У ЛЮДЕЙ 3 ВАДАМИ СЛУХУ В ЇХНЬОМУ СОЦАЛЬНОМУ ЖИТТІ
}

УдК: 616.891.6 - 02:616.284-004

\section{Максименко Сергій Дмитрович}

Доктор психологічних наук, професор, дійсний член Національної академії педагогічних наук $У_{\kappa-}$ раӥни, директор Інституту психологї імені $Г$. С. Костюка Національної академії педагогічних наук України, м. Киів (України)

\section{Яковлева Наталія Юрӥвна}

Аспірантка кафедри загальної і медичної психології та педагогіки Національного медичного університету імені О. О. Богомольия Міністерства охорони здоров'я України та лабораторії психології навчання ім. I. О. Синииі Інституту психології імені Г. С. Костюка Національної академії педагогічних наук України, м. Київ (Украӥни)

Анотація. Статтю присвячено дослідженню особливостей перебігу, поширеності та домінуючим ознакам генералізованого тривожного розладу (ГТР) у людей з порушенням слуху на прикладі отосклерозу. Зазначено, щуо нова міжнародна класифікація психічних розладів DSM-V, опублікована Американською психіатричною асочіачією (2013-2018 р.р.), представляє користувачеві низку змін, покликану полегшити діагностику ГТР у людей з вадами слуху. Вчасна психодіагностика ГТР та використання індивідуального підходу до осіб з порушенням слуху у вигляді психокорекиійних методик когнітивно-поведінкової терапї (КПТ) прискорює процес лікування такого соматичного захворювання, як отосклероз, та запобігає розвитку й загостренню виявлених тривожних симптомів, які провокують виникнення ГТР. В нашій роботі ми розглянемо генералізований тривожний розлад, який достатньо часто зустрічається серед пацієнтів на отосклероз.

Ключові слова: генералізований тривожний розлад (ГTP), DSM-V, тривожні розлади, порушення слуху, отосклероз.

Постановка проблеми. Матеріали масових соціологічних досліджень населення України свідчать про те, що число людей 3 соціально-неадекватним слухом становить від $0,65 \%$ до $2 \%$ осіб. Порушення слуху у людей сприяє розвитку генералізованого тривожного 
розладу (ГТР) [2, с. 320]. Вчасна психодіагностика ГТР та використання індивідуального підходу до таких працівників у вигляді психокорекційних методик когнітивно-поведінкової терапії (КПТ) прискорює процес лікування та запобігає розвитку та загостренню виявлених тривожних симптомів [1,c. 150; 2,с. 410].

Аналіз останніх досліджень і публікацій. Вивченням психологічних характеристик, які суттєво утруднюють перебіг отосклерозу та впливають на ймовірність виникнення порушень тривожного спектру, у тому числі, генералізованого тривожного розладу, займалися такі відчизняні вчені, як: А. П. Страхов, який досліджував певні реакції організму на стресові ситуації; М. I. Пірен, який вивчав міжособистісні та внутрішньоособистісні конфлікти; В. М. Крайнюк, Ч. Д. Спилбергер, Ю. Л. Ханін, які визначали рівень тривожності; К. С. Максименко, що вивчав особливості психічних станів у соматичних хворих; В. А. Кожевникова, яка визнала особливості особистості та поведінкові зміни у осіб, що пережили екстремальні події, Т. В. Шмігель, який довів психологічні аспекти 3 хронічними соматоформними больовими розладами.

Як вказує С. Д. Максименко, існують клініко-патогенетичні взаємозв'язки соматичної і психічної патології, які являються багатогранними. Автор вказуює, що суб'єктивні переживання психічного стану хворих запускають складні фізіологічні процеси, під час яких можуть спостерігатися окрім психічних змін порушення серцевого ритму, частоти дихання, зміна циркуляції крові, зміни в м'язовій системі, запоморочення. На думку С. Д. Максименко, сутність будь-якої хвороби слід розглядати з позиції особистості, що дозволяє проникнути у розуміння психічних процесів, які призводять до виникнення різних психосоматичних захворювань, супроводжують та впливають на перебіг соматичного захворювання, пояснюють виникнення психічних розладів та зумовлюють патопсихологічні, психогенні та соціогенні розлади особистості [1, c. 19].

Проблематикою психологічних особливостей соматичних пацієнтів займалися як вітчизняні науковці, серед яких О. М. Борисенко, Д. І. Заболотний, так і такі зарубіжні вчені, як I. Culpepper, C. Kessler, H. Wittchen, $W$. Maier, C. Mackenzie, E. Martens, K. Yonkers, B. $Z h u$, але психологічний статус на сьогоднішній день ними недостатньо охоплений, тому ми звернули увагу на один із найбільш поширених в нашому суспільстві розлад тривожного спектру, як генералізований тривожний розлад (ГТР), який особливо притаманий людям 3 вадами слуху, на прикладі отосклерозу, у зв'язку із виникненням тих труднощей, яких їм постійно приходиться долати в суспільному середовищі.

Аналіз наукової зарубіжної літератури показав, що ступінь впливу генералізованого тривожного розладу визначається змінами, особливо обмеженнями, які спричиняє ГТР 
хворим на отосклероз (C. Frias, L. Caballero, E. Sawas, J. Maurer, E. Vartiainen, $H$. Niedermeyer, A. Bittermann, A. Huber, M. Toc, R. Haberman, A. Bittermann), а саме: зниженнями функціональних можливостей організму та працездатності, патогенними психічними реакціями та психогеніями, зміною соціального статусу, сімейним функціонуванням в аспекті перерозподілу ролей та обов'язків [2, c. $245 ; 5$, c. $36-39 ; 6$, c. $4-7 ; 8 ; 10 ; 11 ; 12]$.

Генералізований тривожний розлад це постійне виражене почуття напруженості, занепокоєння та майбутніх неприємностей у повсякденних подіях й проблемах протягом декількох місяців [3,с. 240]. Так K. Rickels пояснює труднощі та помилки, з яким доводиться стикатися сучасним медичним психологам, під час діагностування ГТР . Так, на його думку, відрізнити ГТР від панічного розладу неважко, якщо у пацієнта є часті, спонтанні панічні атаки та агорафобічні симптоми. Однак, у багатьох пацієнтів з ГТР трапляються тривожні напади або панічні атаки. Таких пацієнтів, 3 точки зору K. Rickels, слід розглядати як такі, що мають ГТР. Автор припускає, що існує ще більш близький збіг між ГТР та соціальною фобією. Пацієнтів з чітко вираженою фобічною уникаючою поведінкою можна легко відрізнити від пацієнтів з ГТР, але пацієнти з соціальною тривожністю без чіткої фобічної уникаючої поведінки можуть перетинатися 3 пацієнтами з ГТР й, можливо, повинні бути діагностовані як ті, що мають ГТР [5, с. 40].
G. A. Fava стверджує, що найбільш частим тривожним розладом являється генералізований тривожний розлад (10,3\%), пов'язаний із синдромами соматизації, типом поведінки та дратівливістю. Зі слів G. A Fava отримані дані свідчать про те, що тривожні розлади $є$ загальними для багатьох соматичних захворювань, та передбачається, що й для хворих на отосклероз з порушенням слуху. Автор стверджує, що тривожні розлади пов'язані 3 декількома типами психосоматичних симптомів. Результати дослідження вказали на те, що тривожні розлади мають важливі клінічні наслідки під час діагностування соматичних захворювань [6, с. 9].

Метою статті $є$ виявлення особливостей перебігу, поширеність та домінуючі ознаки генералізованого тривожного розладу (ГTP) у форматі DSM-V у людей з порушенням слуху на прикладі отосклерозу.

\section{Виклад основного матеріалу з обгру-} нтуванням отриманих наукових результатів. В первинній ланці медичної допомоги ГТР є найчастішим 3 тривожних розладів. За епідеміологічними оцінками поширеність генералізованого тривожного розладу (ГТР) протягом 12 місяців коливається в межах 1$4 \%$ осіб, а поширеність протягом життя становить приблизно $6 \%$ світового населення відповідно [2, с. $187 ; 4$, с. $3-8$;7, с. 34]. ГТР частіше зустрічається у європеоїдів в порівнянні з іншими групами. Середній вік початку захворювання становить приблизно 31-35 ро- 
ків [9]. Поширеність ГТР оцінюється в 10,8\% у підлітків віком до 15 років [10]. Деякі дані свідчать про те, що жінки можуть в два-три рази частіше страждати від ГТР, ніж чоловіки [1, с. 59] А також ГТР може бути більш поширеним у людей похилого віку [2, с. 56]. Цей розлад, як повідомляється, часто розпізнається менш ніж в однієї третини пацієнтів, які отримують адекватне лікування [12]. ГТР пов'язаний з функціональними [6, с.10;7, с. 36; 9], професійними [10;11;12] порушеннями, 3 погіршенням якості життя $[5$, с. $37 ; 8]$. Крім того, в охороні здоров'я 60-94\% пацієнтів 3 ГТР повідомляють хворобливі фізичні симптоми $[2$, с. $78 ; 4$, с. $6 ; 7$, с. 31$]$, які були основною причиною первинного звернення до лікаря - в 72\% випадків [2, с. 49; 5, с. 35]. ГТР пов'язаний з високими показниками коморбідних психічних розладів, включаючи інші тривожні розлади. Ризик захворювань також підвищено - виникнення больових синдромів [5, c. 38], розвиток гіпертензії [6, с. 5; 7, с. 34], а також захворювання серцево - судинної системи та шлунково-кишкового тракту [10;12]. Наявність ГТР у соматичних хворих на отосклероз збільшує тяжкість захворювання, функціональні порушення, а також економічні витрати [11].

На думку авторів, середній вік початку ГТР дорівнює 21 рік, але віковий розподіл на момент початку захворювання має «двогорбий» тип: первинний ГТР може починатися вже близько 13 років, а вторинний по відношенню до інших тривожних розладів як правило, після 30 років. ГТР має багаторічний хвилеподібний перебіг, загострюючись після стресових подій. Через 5 років від початку спонтанна повна ремісія відзначається лише у третини хворих. Як правило, до моменту постановки діагнозу тривалість ГТР становить 5-10 років [2, с. 210; 4, с. 6].

\section{Генералізований тривожний розлад} (F41.1) - стан, який має хронічний характер i супроводжується надмірною тривогою та занепокоєнням, нерідко беззмістовним, почуттям внутрішньої напруги та вегетативними симптомами, інтенсивність яких менша, ніж за панічного розладу. Хворі відчувають внутрішню дрож, вони $є$ полохливими, у всіх справах передбачають найгірший результат. Пацієнти є нетерплячими, дратівливими, суєтними [3, с. 259].

Головною ознакою генералізованого тривожного розладу (ГТР) є постійна тривога, відмінною рисою якої $є$ постійна наявність тривоги на протязі тривалого часу, тобто тривога набуває хронічного характеру. При ГТР надмірна хронічна тривога підтримується тривожними очікуваннями, які постійно виникають, та занепокоєнням. Зазначена стурбованість виникає з різних, не пов'язаних один з одним приводів (наприклад, стан здоров'я, робота та ін.). При цьому готовність до виникнення тривоги залишається навіть тоді, коли турбуючі хворого події благополучно вирішуються [2, с. $126 ; 3$, с. 82]. 
Так за міжнародною класифікацією хвороб (MКХ-10) генералізований тривожний розлад (ГТР) характеризується певними ознаками, а саме:

МKX-10 F41.1. Генералізований тривожний розлад.

А. Період щонайменше шість місяців 3 вираженою напруженістю, занепокоєнням й почуттям майбутніх неприємностей у повсякденних подіях та проблемах.

Б. Повинні бути присутніми щонайменше чотири симптоми 3 наступного списку, причому один 3 них 3 переліку 1-4:

1) посилене або прискорене серцебиття;

2) пітливість;

3) тремор або тремтіння;

4) сухість у роті (але не від ліків або дегідратації);

Симптоми, які відносяться до грудей i живота:

5) труднощі в диханні;

6) відчуття задухи;

7) біль або дискомфорт у грудях;

8) нудота або абдомінальний дистрес (наприклад, печіння в шлунку);

Симптоми, пов'язані з психічним стаHOM:

9) почуття запаморочення, нестійкості або непритомності;

10) почуття, що предмети нереальні (дереалізація) або що власне Я віддалилося або «по справжньому знаходиться не тут»;
11) страх втрати контролю, божевілля або наступаючої смерті;

12) страх померти;

Загальні симптоми:

13) припливи або озноб;

14) оніміння або відчуття поколюван-

ня;

Симптоми напруги:

15) м’язова напруга або біль;

16) занепокоєння та нездатність до релаксації;

17) почуття нервозності, «на взводі» або психічної напруги;

18) відчуття грудки в горлі або утруднення при ковтанні;

Інші неспецифічні симптоми:

19) посилене реагування на невеличкі сюрпризи або на переляк;

20) труднощі в зосередженні уваги або «пустота в голові» через тривогу або занепокоєння;

21) постійна дратівливість;

22) утруднення при засипанні через занепокоєння.

В. Розлад не відповідає критеріям панічного розладу (F41.0), тривожно-фобічних розладів (F40), обсесивно-компулсівного розладу (F42) або іпохондричного розладу (F45.2).

Г. Найбільш часто використовувані критерії виключення. Тривожний розлад не обумовлений фізичним захворюванням, таким як гіпертиреоїдизм, органічним психічним ро- 
зладом (F10-F09) або розладом, пов'язаним 3 вживанням психоактивних речовин (F10-F19), таким як надмірне вживання амфетаміноподібних речовин або скасування бензодіазепінів.

Психологи виділяють слідуючі клінічні діагностичні критерії ГТР:

1. Частіше зустрічається у 20-річних осіб, але може бути й в іншому віці.

2. Частіше у жінок, ніж у чоловіків $(2: 1)$.

3. Підвищена тривожність і занепокоєння про майбутнє своє та близьких.

4. Тривалість розладу не менше декількох тижнів, частіше - місяців.

5. Моторна напруга (тремтіння, посмикування, відчуття ознобу, неможливість розслабитися, головний біль, почуття хвилювання, неможливість зосередитися).

6. Вегетативна гіперактивність (пітливість, тахікардія або тахіпное, запаморочення, сухість у роті, слабкість, епігастральні розлади, гіперемія, утруднене ковтання).

7. Відчуття напруженості.

8. Перебільшена сторожкість.

9. Порушення сну.

10. Дратівливість.

Також доцільно перерахувати типові стереотипи мислення, що часто зустрічаються при ГТР, а саме: «Людина людині вовк, кожен в цьому житті тільки за себе», «Я не маю права на помилку», «Я повинен все робити «на п’ятірку», «Якщо хтось негативно оцінив ме- не, значить, я нічого не коштую», «Я відповідаю за все, що відбувається в цьому житті», «Будь-яке нездужання може бути початком серйозної хвороби», «Я кволий, нездатний самостійно справлятися 3 труднощами життя», «Я зійду з розуму», «Я просто помру», «Люди зайняті тільки собою, байдужі, зневажають слабких», «Людям не можна довіряти», «Я не маю права на помилку, я завжди повинен бути на висоті», «Якщо хтось не звертає на мене уваги, значить він зневажає мене», «Будь-яка помилка може мати серйозні і важкі наслідки для подальшого життя», «На мене всі дивилися $з$ осудом», «Я виглядав, як повна нікчемність», «Про себе вони сміялися наді мною» та інше.

Слід зауважити, що існують певні фактори, які можуть призвести до розвитку ГТР (фактори ризику), а саме:

1. Статева приналежність: у жінок ГТР зустрічається в два рази частіше, ніж у чоловіків (природня схильність надмірно «приймати все близько до серця»);

2. Дитяча психічна травма: ті, хто пережив травматичні події в дитинстві, теж мають більше шансів на ГТР.

Наприклад, в період дитинства пацієнта спіткала психологічна травма: $з$ ним погано спілкувалися в сім'ї, помер один з батьків, був виявлений синдром жорстокого поводження 3 дітьми й інше. Тобто після перенесеного великого стресу (сімейна криза та ін.) розвинувся генералізований тривожний розлад (ГТР). 
Криза завершилася, провокуючі фактори вичерпалися, але ознаки ГТР збереглися. Відтепер будь-який дрібний стрес, впоратися 3 яким завжди було просто, підтримує симптоми захворювання.

Іншою причиною можуть бути помилкові дії батьків та вчителів: зайва критика, нереалістичні вимоги, невизнання достоїнств та досягнень дитини, відсутність емоційної підтримки в значущих ситуаціях (депресії i стреси, перенесені в дитинстві).

3. Соматичне тяжке захворювання: таке як захворювання отосклероз (а також такі, як коронарна хвороба серця, гіпертиреоз, гіпоглікемія, фєохромоцитома, легенева емболія, бронхіальна астма, сифіліс, епілепсія, мігрень, розсіяний склероз), яке у зв'язку з втратою слуху може викликати занепокоєння про майбутнє, про лікування та інше.

4. Стрес: стресові ситуації (фізичне, сексуальне або психологічне насильство), або інші стресові ситуації, особливо якщо вони відбуваються одночасно й у великій кількості, можуть привести до почуття розгубленості та викликати тривожність, а в результаті і ГТР (недостатня стійкість до стресів). Так, наприклад, постановка неправильних цілей в житті, вірніше їх завищення, - вже початковий неуспіх призводить до зайвих переживань, а темп сучасного життя, який все прискорюється, тільки підливає «масла у вогонь».

5. Особистісні характеристики: конституційні особливості (повні люди менш схи- льні до появи ГТР); певні риси (вразливі, ранимі, схильні приховувати свої переживання від оточуючих), особливо у тих, у кого є незадоволені потреби (довга бідність та відсутність перспектив поліпшення матеріального становища) й хронічне відчуття незахищеності, а також у людей з особистісним психічним розладом в анамнезі 3 історії хвороби (наприклад, пограничний розлад особистості, алекситимія (недостатня здатність розпізнавати та висловлювати власні почуття) та інше).

6. Спадковість: генетично обумовлена схильність тривожитися з незначних приводів. Факти, які підтверджують, що ГТР носить спадковий характер: в сімейній історії хвороби є синдроми тривожності, тобто в роду багато тривожних особистостей (наприклад, родичі, які перенесли ГТР).

7. Коморбідність: ГТР часто проявляється в поєднанні з іншими розладами. Часто його супроводжують інші тривожні розлади (панічний розлад, обсесивно-компульсивний розлад (ОКР), посттрасоціальна фобія (СФ), специфічна фобія (СпФ)), депресія й інше. В анамнезі таких хворих можна виявити вматичний стресовий розлад (ПТСР), і поодинокі панічні атаки.

\section{8. Соціальні фактори: погіршення сто-} сунків у сім’і, тобто проблемне сімейне життя або неможливість їі вчасно влаштувати, конфлікт на роботі, грошові питання, навколишнє середовище, стан справ на місцевому, національному або глобальному рівні (наприклад, 
незадоволеність шлюбом, сім'єю, навчальними або спортивними показниками й інше) або зміна звичного розпорядку (вступ до інституту, переїзд, пристрій на нову роботу та інше);

\section{9. Занижена самооцінка;}

10. Малорухливий спосіб життя;

11. Куріння, зловживання алкоголем, наркотичними речовинами, психоактивними речовинами - стимуляторів (міцної кави, тонізуючих напоїв) та деяких лікарських препаратів (симпатоміметики, антидеприсанти, бензодіазепіни, теофлін, бронхіальні препарати, для невідкладної терапії (для купірування гострих нападів) та ін.).

Міжнародна група з вироблення рекомендацій по ГТР пропонує психотерапевтам або медичним психологам з метою скринінгу на ГТР задавати пацієнту два питання: 1) Чu відчували Ви більшу частину часу за останні 4 тижні занепокоєння, напругу або тривогу? 2) Чи часто у Вас буває відчуття напруженосmi, дратівливість та порушення сну? Якщо хоча б на одне $з$ цих питань дано позитивну відповідь, необхідно поглиблене розпитування 3 метою активного виявлення симптомів ГТР.

Категорія генералізованого тривожного розладу (ГТР), безумовно, зручна для професійного застосування, залишається одією 3 найбільш успішних у форматах МКБ-I0 i DSM-V. Нова міжнародна класифікація психічних розладів DSM-V представляє користувачеві низку змін, покликаних полегшити діагностику ГTP (GAD) у людей з вадами слуху в сучасному соціальному середовищі, які часто стикаються $з$ даною проблемою у своєму повсякденному та професійному житті [3, c. 51].

DSM-V Критеріями генералізованого тривожного розладу (ГТР) є:

- наявність в особи надмірного занепокоєння та заклопотаності (тривожного очікування) щодо низки подій або діяльності (наприклад, робота чи успішність у навчанні);

- особі важко контролювати своє занепокоєння;

- надмірне занепокоєння та заклопотаність особи пов'язані з $\geq 3$ із нижче вказаних симптомів, що при цьому виникають у більшості днів протягом $\geq 6$ попередніх місяців:

$\Rightarrow$ відчуття занепокоєння, роздратування чи перебування на межі,

$\Rightarrow$ швидка стомлюваність,

$\Rightarrow$ труднощі з концентрацією уваги,

$\Rightarrow$ дратівливість,

$\Rightarrow$ м'язова напруга,

$\Rightarrow$ порушення сну.

Як наслідок, симптоми викликають клінічно значущий дистрес або функціональні порушення.

Для визначення генералізованого тривожного розладу (ГТР) нами використовується Опитувальник для визначення генералізованого тривожного розладу (GAD-7), як відображено в Таблиці 1. 
Дослідження особливостей перебігу, поширеності та домінуючих ознак генералізованого тривожного розладу (ГТР) в форматі DSM-V у людей з порушенням слуху проводилося в Інституті оториноларингології ім. проф. О. С. Коломійченка НАМН України на пацієнтах з отосклерозом. В даному дослідженні взяло участь загалом 246 особи, серед яких було виявлено 156 осіб з тривожними розладами, де було діагностовано 18 (11,54 \%) пацієнтів з ГТР.

Поширеність ГТР у хворих на отосклероз протягом 1 року коливається від $1-4 \%$.
При опитуванні пацієнтів також з'ясувалося, що поширеність ГТР протягом життя становить приблизно 6 \%. В основному ГТР спостерігалася у пацієнтів з отосклерозом в $30-35$ років. Було відзначено, що жінки з отосклерозом в два-три рази частіше страждають від ГТР, ніж чоловіки та ГТР більш поширений серед літніх людей.

При опитуванні у хворих на отосклероз при наявності симптомів ГТР відзначалися функціональні та професійні порушення. Крім того, 60 - 94 \% пацієнтів з отосклерозом, які мали ГТР, повідомляли хворобливі фізичні

Таблиия 1.

\section{Опитувальник для визначення генералізованого тривожного розладу (GAD-7)}

\begin{tabular}{|c|c|c|c|c|}
\hline \multirow[t]{2}{*}{$\begin{array}{l}\text { Як часто за останні } 2 \text { неділі Вас турбували наступні } \\
\text { проблеми? }\end{array}$} & $\begin{array}{l}\text { Ніколи } \\
\text { (не було } \\
\text { взагалі) }\end{array}$ & $\begin{array}{c}\text { Декіль- } \\
\text { ка } \\
\text { 0-4 } \\
\text { Днів } \\
\text { (іноді) }\end{array}$ & $\begin{array}{c}\text { Більше } \\
\text { половини } \\
\text { днів } \\
\text { (часто) }\end{array}$ & $\begin{array}{c}\text { Майже } \\
\text { кожного } \\
\text { дня } \\
\text { (практичн } \\
\text { о } \\
\text { постій- } \\
\text { но) }\end{array}$ \\
\hline & $\langle 0 »$ & «1» & $\ll 2 »$ & «3» \\
\hline \multicolumn{5}{|l|}{$\begin{array}{l}\text { 1.Підвищена нервова збудже-ність, неспокій або роздрату } \\
\text {-вання (відчуття «На грані зриву») }\end{array}$} \\
\hline \multicolumn{5}{|l|}{ 2. Нездібність справитися з хвилюванням } \\
\hline \multicolumn{5}{|l|}{ 3. Надмірне занепокоєння з різних приводів } \\
\hline \multicolumn{5}{|l|}{ 4. Нездібність розслаблятися } \\
\hline \multicolumn{5}{|l|}{$\begin{array}{l}\text { 5.Крайня ступінь занепокоєн-ня: не можу знайти собі міс- } \\
\text { це (непосидючість) }\end{array}$} \\
\hline \multicolumn{5}{|l|}{$\begin{array}{l}\text { 6. Легко піддаюсь почуттю занепокоєння чи роздрату- } \\
\text { вання (дратівливість і нестри-маність) }\end{array}$} \\
\hline 7.Побоювання чогось страш-ного. & & & & \\
\hline
\end{tabular}

\begin{tabular}{|l|l|}
\hline Сума балів & Рівень тривожності \\
\hline $0-4$ & Мінімальний (мінімальна) \\
\hline $5-9$ & Середній (легка) \\
\hline $10-14$ & Помірний (помірна) \\
\hline $15-21$ & Високий (важка) \\
\hline
\end{tabular}


симптоми у вигляді помірних та інтенсивних головних болів, посилення шуму у вухах й погіршення слуху, які в 72\% випадків були основною причиною первісного звернення до лікаря.

При наявності ГТР у пацієнтів 3 отосклерозом підвищується ризик таких захворювань, як гіпертонія, серцево-судинні захворювання та захворювання шлунково-кишкового тракту. Наявність ГТР у пацієнтів з отосклерозом збільшує тяжкість самого захворювання, а також викликає такі функціональні порушення, як головні болі, болі в серці, підвищення артеріального тиску, розлад шлунку та інше. Все це в кінцевому разі у пацієнтів з отосклерозом призводить до великих економічних витрат.

ГТР у хворих на отосклероз (Ото) характеризується надмірною тривогою та занепокоєнням про те, з якими труднощами пацієнтам доводиться постійно стикатися в таких життєвих ситуаціях, як навчання чи робота, що є очевидним протягом багатьох днів на протязі попередніх шести місяців. Крім того, ГТР у пацієнтів з отосклерозом пов'язан із занепокоєнням, напругою м'язів тіла, втомою, труднощами в концентрації уваги, дратівливістю й розладами сну.

3 ціллю психотерапії специфічного тривожного розладу у хворих на отосклероз були застосовані методи когнітивноповедінкової терапії (КПТ).

Результати дослідження показали, що когнітивно-поведінкова терапія (КПТ) у хворих на отосклероз є ефективним засобом для психокорекції генералізованого тривожного розладу (ГТР) $[4 ; 5 ; 6 ; 7 ; 8 ; 9 ; 10 ; 11 ; 12]$. Проведений нами мета-аналіз на експериментальній групі у хворих на Ото ясно показує, що КПТ значно зменшує симптоми ГТР. Індивідуальна і групова терапія представляється в нашому випадку у пацієнтів з Ото в рівній міpi ефективними 3 точки зору зниження симптомів тривоги, але індивідуальна терапія може привести до більш раннього поліпшення при неспокої і інших тривожних симптомах при ГТР.

Інтенсивність когнітивно-поведінкової терапії для пацієнтів з Ото оцінювали в метааналізі у 72 хворих на Ото, серед яких було 9 (12,50\%) пацієнтів з ГТР. Схеми психокорекції, включно інтенсивні режими - 1-2 сеанси в межах стаціонару, були ефективні з вісьма або більше симптомах тривоги та, взагалі, зменшували інтенсивність симптомів тривоги у хворих на Ото з ГТР.

Кілька наших досліджень показали користь психокорекції на базі Інтернету на основі програм КПТ (ІКПТ) [7, с. 31; 8; 12].

Мета-аналіз досліджень ГТР в експериментальній групі пацієнтів 3 Ото не виявив істотних відмінностей між КПТ і релаксаційною терапією. Однак, більш пізні дослідження, проведені протягом 1,5 місяців, демонструють, що релаксація має обмежену ефективність. Бальнеотерапія, терапія релаксації, що 
включає спа-процедури, продемонструвала та довела потенційні переваги в поліпшенні оцінки стану тривоги у хворих на Ото з ГТР [5, с. $35 ; 6$, с. 7]. Так пацієнтами експериментальної групи з Ото після проведеного строку психокорекційних методик поза межами стаціонару на протязі 1,5 місяця були виявлені симптоми ГТР у 3 (9,10 \%) осіб після повторного діагностування, що значно менше у хворих на Ото під час знаходження в межах стаціонару в період після оперативного втручання.

Когнітивно-поведінкова терапія (КПТ) проти нетерпимості до невизначеності продемонстрували ефективність у хворих на Ото 3 ГТР. В даному випадку КПТ була орієнтована до тривоги, а також до уразливості, яка насувається (схильність створювати й підтримувати внутрішні сценарії підвищення ризику та небезпеки) була ефективною.

Під час попередньої обробки мотиваційного інтерв'ювання КПТ у хворих на Ото 3 ГТР було виявлено зменшення опору до психокорекції, поліпшення дотримання домашніх завдань, а також поліпшення результатів переживання, таким чином КПТ може виявитися особливо корисною в більш важких випадках $[10 ; 11 ; 12]$. В клінічній практиці такий підхід, можливо, повинен бути індивідуалізований до проблем, випробовуваних хворими на Ото.

Наступні дані з нашого мета-аналізу 3 приводу КПТ припускають, що користь від психологічних методів лікування зберігається на протязі 1,5 місяців.
ГТР у пацієнтів з Ото даної групи пов’язаний зі значними функціональними порушеннями. Відповідно до критеріїв DSM-V, ГТР характеризується надмірною тривогою й занепокоєнням 3 декілька ситуацій та м'язовою напругою і поведінковими змінами, пов'язаними із занепокоєнням.

Нами було доведено, що КПТ у хворих на Ото з ГТР - це ефективний варіант для лікування ГТР. Також можна засвідчити, що на основі інтернету та комп'ютерних програм когнітивно-поведінкова терапія (КПТ) також продемонструвала ефективність у пацієнтів 3 отосклерозом (Ото).

Висновки. При проведенні дослідження було виявлено, що прогресування зниження слуху у пацієнтів із захворюванням отосклероз, з постановкою діагнозу «отосклероз» сприяло розвитку генералізованого тривожного розладу (ГTP) в форматі DSM-V. Також встановлено, що для пацієнтів з ГТР характерна коморбідність. Також результати дослідження показали, що когнітивноповедінкова терапія (КПТ) у хворих на отосклероз є ефективним засобом для психокорекції генералізованого тривожного розладу (ГТР).

\section{Перспективи подальших розвідок} вбачаємо в розумінні відмінностей, психологічного змісту, негативних аспектів ГТР в форматі DSM-V в поєднанні з визначенням захворювання отосклероз із порушенням слуху, які постали як важлива складова для побудови 
комплексної диференційованої програми медико-психологічної допомоги людині з вадами слуху.

\section{Перелік використаних джерел:}

1. Максименко С. Д. Медична психологія / С. Д. Максименко.- Вінниця : Нова книга, 2010. - 515с.

2.Роджерс К. Р. Консультирование и психотерапия. Новейшие подходы в области практической работы / K. Р. Роджерс. - М.:Эксмо-Пресс ,2008. -512 с.

3. Шкуренко Д. А. Общая и медицинская психология / Д. А. Шкуренко.-Ростов - на - Дону:ФЕНИКС,2002.$352 \mathrm{c}$.

4. American Psychiatric Association: Diagnostic and Statistical Manual of Mental Disorders (DSM-V). Washington, DC: American Psychiatric Association, Fifth, 2013.

5. Culpepper $L$. Generalized anxiety disorder in primary care: emerging issues in management and treatment / $\mathrm{L}$. Culpepper // J Clin Psychiatry.- 2002.- №63. -P.35-42.

6. Kessler R. C. Patterns and correlates of generalized anxiety disorder in community samples / R. C. Kessler, H. U. Wittchen // J Clin Psychiatry .-2002.-№63(suppl 8). P.4-10.

7. Maier $W$. Generalized anxiety disorder (ICD-10) in primary care from a cross cultural perspective: A valid diagnostic entity / [W. Maier, M. Gaensicke, H. J. Freyberger, M. Linz] // Acta Psychiatr Scand .- 2000.№101. - P. 29-36.

8. Mackenzie C. S. Prevalence and correlates of generalized anxiety disorder in a national sample of older adults / [C. S. Mackenzie [and others] // J. Geriatr Psychiatry.- 2011.- № 19.- Р.305-315.-Режим доступу до журн.:https:// www.ncbi.nlm.nih.gov/pmc/articles/PMC2933177/

9. Martens E. J. Scared to death? Generalized anxiety disorder and cardiovascular events in patients with stable coronary heart disease: The Heart and Soul Study / [E. J. Martens [and others] //Arch. Gen. Psychiatry.- 2010.- №
67.- P.750-758.-Режим доступу до журн.: https:// www.ncbi.nlm.nih.gov/pubmed/20603456?dopt=Abstract 10. Van Ameringen M. Generalized Anxiety Disorder / M. Van Ameringen, M. Pollack // New York: Oxford University Press.- 2010.- P.89-100.

11. Yonkers K. A. Factors predicting the clinical course of generalized anxiety disorder / [K. A. Yonkers, I. R. Dyck, M. B. Keller, S. E. Bruce] // Br J Psychiatry .- 2000.№176. - P. 544-550.

12. Zhu B. The cost of comorbid depression and pain for individuals diagnosed with generalized anxiety disorder / [ B. Zhu [and others] // J. Nerv. Ment. Dis.- 2009.-№ 197.P.136-139.-Режим доступу до журн.:https:// www.researchgate.net/publication/310477738

\section{References (Transliteration):}

1. Максименко С. Д. Медична психологія / С. Д. Максименко.- Вінниця : Нова книга, 2010. $-515 \mathrm{c}$.

2. Роджерс K. Р. Консультирование и психотерапия. Новейшие подходы в области практической работы / К. Р. Роджерс. - М.:Эксмо-Пресс ,2008. -512 с.

3. Шкуренко Д. А. Общая и медицинская психология / Д. А. Шкуренко.-Ростов - на - Дону:ФЕНИКС,2002.$352 \mathrm{c}$.

4. American Psychiatric Association: Diagnostic and Statistical Manual of Mental Disorders (DSM-V). Washington, DC: American Psychiatric Association, Fifth, 2013.

5. Culpepper $L$. Generalized anxiety disorder in primary care: emerging issues in management and treatment / L. Culpepper // J Clin Psychiatry.- 2002.- №63. -P.35-42.

6. Kessler R. C. Patterns and correlates of generalized anxiety disorder in community samples / R. C. Kessler, H. U. Wittchen // J Clin Psychiatry .-2002.-№63(suppl 8). P.4-10.

7. Maier $W$. Generalized anxiety disorder (ICD-10) in primary care from a cross cultural perspective: A valid diagnostic entity / [W. Maier, M. Gaensicke, H. J. Freyberger, M. Linz] // Acta Psychiatr Scand .- 2000.Яковлева Н. Ю. 
№101. - P. 29-36.

8. Mackenzie C. S. Prevalence and correlates of generalized anxiety disorder in a national sample of older adults / [C. S. Mackenzie [and others] // J. Geriatr Psychiatry.- 2011.- № 19.- Р.305-315.-Режим доступу до журн.:https:// www.ncbi.nlm.nih.gov/pmc/articles/PMC2933177/

9. Martens E. J. Scared to death? Generalized anxiety disorder and cardiovascular events in patients with stable coronary heart disease: The Heart and Soul Study / [E. J. Martens [and others] //Arch. Gen. Psychiatry.- 2010.- № 67.- Р.750-758.-Режим доступу до журн.: https:// www.ncbi.nlm.nih.gov/pubmed/20603456?dopt=Abstract 10. Van Ameringen M. Generalized Anxiety Disorder / M. Van Ameringen, M. Pollack // New York: Oxford University Press.- 2010.- P.89-100.

11. Yonkers $K$. A. Factors predicting the clinical course of generalized anxiety disorder / [K. A. Yonkers, I. R. Dyck, M. B. Keller, S. E. Bruce] // Br J Psychiatry .- 2000.№176. - Р. 544-550.

12. Zhu B. The cost of comorbid depression and pain for individuals diagnosed with generalized anxiety disorder / [ B. Zhu [and others] // J. Nerv. Ment. Dis.- 2009.-№ 197.P.136-139.-Режим доступу до журн.:https:// www.researchgate.net/publication/310477738

\section{Maksymenko Serhiy}

Doctor of Psychological Science, Professor, Full Member of the National Academy of Educational Sciences of Ukraine, Director of H. S. Kostyuk Institute of Psychology of the National Academy of Educational Sciences of Ukraine, Kyiv (Ukraine)

\section{Iakovleva Nataliia}

Postgraduate student of the department of general and medical psychology and the pedagogy O. O. Bogomolets National Medical University of the Ministry of Health of Ukraine and I. O. Sinitsa Laboratory of Psychology of Education of H. S. Kostyuk Institute of Psychology of the $\mathrm{Na}$ tional Academy of Educational Sciences of Ukraine, Kyiv (Ukraine)

\section{DSM-V FORMAT OF GENERALIZED ANXIETY DISODER IN SOCIAL LIFE OF PEOPLE WITH HEARING IMPAIRMENT}

\section{ABSTRACT}

The article deals with the course, incidence symtoms of generalized anxiety disorder (GAD), according to DSM-V, in people with hearing impairment exemplified by the otosclerosis. It is noted that tlle category of generalized anxiety disorder (GAD) is certainly convenient for professional use, it is one of the most successful formats of ICD-I0 and DSM-V-TR. Pubished in May 2013 by the American Psychiatric Association, a new classification of mental disordeгs DSM-V, presents the user with a number of changes designed to facilitate of the diagnosis of generalized anxiety disorder (GAD) in the people with hearing impairment.

The purpose of the article is to identify the features of the periodicity, prevalence and dominant signs of generalized anxiety disorder (GTR) in the DSM-V format for people with hearing impairment on the example of otosclerosis.

The in article addresses specific psychological features of generalized anxiety disorder (GAD) in patients with otosclerosis. The diagnostic criteria for generalized anxiety disorder (GAD) were chosen according to the DSM-5 international diagnostic classification. The generalized anxiety disorder (GAD) as resulted from otosclerosis have been proven to cause psychological and emotional disorders which can be accompanied by specific mental and behavioral dis- 
orders, and poor social adaptation. The study reveals that patients with otosclerosis who suffer from specific types as the generalized anxiety disorder (GAD) exhibit specific psychological features. The questionnaire GAD - 7 was used as a screening instrument and a research method in the determination of the generalized anxiety disorder (GAD) in patients with otosclerosis, during which it was confirmed to be fully consistent with the tasks assigned. A psychocorrectional program has been developed to overcome and correct of generalized anxiety disorder (GAD) in patients with otosclerosis, which can be used by psychotherapists and medical psychologists in medical institutions.

The timely psychodiagnosis of generalized anxiety disorder (GAD) and the use of an individual approach to hearing impaired people in the form of psycho-correction techniques for cognitive-behavioral therapy (CBT), accelerates the process of treating such a major somatic disease as otosclerosis, and prevents the development and exacerbation of detected anxiety symptoms that provoke the onset of generalized anxiety disorder (GAD). In our work, we will consider the generalized anxiety disorder (GAD) that is most commonly encountered among patients with otosclerosis.

Key words: generalized anxiety disorder (GAD), DSM-V, anxiety disorder, hearing impairment, otosclerosis.

\section{Максименко Сергей Дмитриевич}

Доктор психологических наук, профессор, директор Института психологии имени Г. С. Костюка Наџиональной академии педагогических наук Украинь, г. Киев (Украина)

\section{Яковлева Наталия Юрьевна}

Аспирант кафедры общей и медицинской психологии и педагогики Национального медицинского университета имени А. А. Богомольияа Министерства здравоохранения Украинь и лаборатории психологии обучения им. И. А. Синиць Института психологии имени Г. С. Костюка Наџиональной академии педагогических наук Украины, г. Киев (Украина)

\section{ГЕНЕРАЛИЗОВАННОЕ ТРЕВОЖНОЕ РАССТРОЙСТВО В МЕЖДУНАРОДНОМ ФОРМАТЕ DSM-V У ЛЮДЕЙ С НАРУШЕНИЕМ СЛУХА В ИХ СОЦИАЛЬНОЙ ЖИЗНИ}

Аннотация. Статья посвящена исследованию особенностей протекания, распространенности и доминирующим признакам генерализованного тревожного расстройства (ГTP) в формате DSM-V у людей с нарушением слуха на примере отосклероза. Отмечено, что новая международная классификация психических расстройств DSM-V, опубликованная Американской психиатрической ассоциацией (2013-2018 г.г.), представляет пользователю ряд изменений, призванных облегчить диагностику генерализованного тревожного расстройства (ГТР) у людей с нарушением слуха. Своевременная психодиагностика ГТР и использование индивидуального подхода к людям с нарушением слуха в виде психокоррекционных методик когнитивно- 
поведенческой терапии (КПТ) ускоряет процесс лечения такого соматического заболевания, как отосклероз, и предотвращает развитие и обострение выявленных тревожных симптомов, которые способствуют возникновению ГТР. В нашей работе мы рассмотрим генерализованное тревожное расстройство (ГТР), которое достаточно чаще встречается среди пациентов с отосклерозом.

Ключевые слова: генерализованное тревожное расстройство (ГТР), DSM-V, тревожные расстройства, нарушение слуха, отосклероз. 